\title{
Candida materiae sp. nov., a yeast species isolated from rotting wood in the Atlantic Rain Forest
}

\author{
Correspondence \\ Carlos A. Rosa \\ carlrosa@icb.ufmg.br
}

\author{
Anne C. Barbosa, ${ }^{1}$ Raquel M. Cadete, ${ }^{1}$ Fátima C. O. Gomes, ${ }^{2}$ \\ Marc-André Lachance ${ }^{3}$ and Carlos A. Rosa ${ }^{1}$ \\ ${ }^{1}$ Departamento de Microbiologia, ICB, C.P. 486, Universidade Federal de Minas Gerais, Belo \\ Horizonte, MG, 31270-901, Brazil \\ ${ }^{2}$ Departamento de Química, Centro Federal de Educação Tecnológica de Minas Gerais, Belo \\ Horizonte, MG, Brazil \\ ${ }^{3}$ Department of Biology, University of Western Ontario, London, ON N6A 5B7, Canada
}

\begin{abstract}
Three strains of a novel yeast species, Candida materiae sp. nov., were isolated from rotting wood in an Atlantic rain forest site in Brazil. Analysis of the sequences of the D1/D2 domains of the large-subunit rDNA showed that this species belonged to the Spathaspora clade and was related to Candida jeffriesii and Spathaspora passalidarum. Unlike C. jeffriesii and S. passalidarum, C. materiae sp. nov. did not ferment xylose. The type strain of C. materiae sp. nov. is UFMG-07-

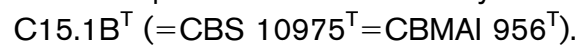

The genus Spathaspora was proposed by Nguyen et al. (2006) to accommodate the single species $S$. passalidarum, a xylose-fermenting yeast isolated from the beetle Odontotaenius disjunctus in Louisiana, USA. The asexual species Candida jeffriesii, Candida lyxosophila and Candida insectamans are phylogenetically related to $S$. passalidarum (Nguyen et al., 2006). C. jeffriesii was isolated from an adult of the beetle Phrenapates bennetti collected in Panama. van der Walt et al. $(1972,1987)$ isolated C. insectamans from a frass sample of beetle larvae in trees and C. lyxosophila from surface woodland soil samples in South Africa, respectively. C. jeffriesii and C. lyxosophila are also able to ferment Dxylose, whereas $C$. insectamans does not ferment this pentose. During a survey of yeasts associated with rotting wood in Atlantic rain forest in Brazil, representatives of a novel yeast species related to the Spathaspora clade were isolated. The isolates were not able to ferment D-xylose and analysis of the sequences of the D1/D2 domains of the large-subunit rRNA gene showed that they were closely related to $C$. jeffriesii. The novel species is described as Candida materiae sp. nov.

The yeast strains were isolated from rotting wood samples collected in the private Natural Heritage Reserve of the Sanctuary of the Caraça. This is an ecological reserve with 11233 ha of Atlantic rain forest located in the Serra do Espinhaço $\left(20^{\circ} 05^{\prime} \mathrm{S} 43^{\circ} 28^{\prime} \mathrm{W}\right)$, state of Minas Gerais, south-eastern Brazil. The region consists of a mountain complex that constitutes a zone of contact between the 'Cerrado' (savannas) and the Atlantic rain forest ecosys-

The GenBank/EMBL/DDBJ accession number for the gene sequence of the D1/D2 domain of the 26S rDNA of strain UFMG-07-C15.1B ${ }^{\top}$ is FJ154790. tems in the south, and a zone of transition from 'Cerrado' to Atlantic forest to 'Caatinga' ecosystem in the north. The reserve has various floristic formations that include seasonal semideciduous forests, 'high-altitude plateaus' and rupestrian fields (grasslands surrounded by rocky outcrops, as well as shrubs and small trees). Seven decayed wood samples were collected on ecological trails of the Reserve of Caraça in November 2007. The samples were stored in sterile plastic bags and transported under refrigeration to the laboratory over a period of no more than $24 \mathrm{~h}$. One gram of each sample was placed separately in flasks with $20 \mathrm{ml}$ sterile carboxymethylcellulose medium $(0.67 \%$ yeast nitrogen base, $1 \%$ carboxymethylcellulose, $0.05 \%$ cellobiose and $0.02 \%$ chloramphenicol), and in $20 \mathrm{ml}$ sterile D-xylose medium $(0.67 \%$ yeast nitrogen base, $0.5 \%$ D-xylose, $0.02 \%$ chloramphenicol). The flasks were incubated at $25{ }^{\circ} \mathrm{C}$ on an incubator shaker (New Brunswick) at 150 r.p.m. for 3-10 days. When growth was detected, $0.5 \mathrm{ml}$ of the cultures was then transferred separately to tubes containing $5 \mathrm{ml}$ sterile carboxymethylcellulose or D-xylose media and the tubes were incubated as described above. One loopfull of solution from each tube was streaked on yeast extract-malt extract agar (YMA; $1 \%$ glucose, $0.3 \%$ yeast extract, $0.3 \%$ yeast malt, $0.5 \%$ peptone, $2 \%$ agar and $0.02 \%$ chloramphenicol). The plates were incubated at $25{ }^{\circ} \mathrm{C}$ until yeast colonies developed. The different yeast morphotypes were purified by repeated streaking on YMA plates and preserved at $-80{ }^{\circ} \mathrm{C}$ or in liquid nitrogen for later identification. The yeasts were characterized by using standard methods (Yarrow, 1998). Fermentation of D-xylose was tested in Durham tubes containing $2 \%(\mathrm{w} / \mathrm{v})$ solution of the sugar. The tubes were incubated at $25{ }^{\circ} \mathrm{C}$ on an incubator shaker 
(New Brunswick) at 80 r.p.m. for 3-20 days. Candida shehatae var. shehatae CBS 5813, C. shehatae var. insectosa CBS 4286, C. shehatae var. lignosa CBS 4705 and Pichia stipitis CBS 5773 were used as positive controls for D-xylose fermentation. Preliminary identifications followed the taxonomic keys of Kurtzman \& Fell (1998).

The D1/D2 variable domains of the large-subunit rDNA were amplified by PCR directly from whole cells as described previously (Lachance et al., 1999). The amplified DNA was concentrated and cleaned on QIAquick PCR columns (Qiagen) and sequenced using an ABI sequencer at the John P. Robarts Research Institute, London, Ontario, Canada. The sequence was edited with the program DNAMAN, version 6 (Lynnon BioSoft). Existing sequences for other yeasts were retrieved from GenBank. The CLUSTAL w software (Thompson et al., 1994) was used to align the sequences and construct a neighbour-joining tree with 1000 bootstrap iterations.

\section{Species delineation, classification and ecology}

Analysis of the sequences of the D1/D2 region of the largesubunit rRNA gene showed that Candida materiae sp. nov. belonged to the Spathaspora clade (Fig. 1). In terms of sequence divergence, C. materiae sp. nov. differed by 13 substitutions from $C$. jeffriesii, and by 20 substitutions from S. passalidarum. Three strains (UFMG-07-C12.1, UFMG$07-\mathrm{C} 15.1 \mathrm{~B}^{\mathrm{T}}$ and UFMG-07-C27.1) of the novel species were isolated from samples of rotting wood collected in the Atlantic rain forest of the Reserve of Caraça. These three strains of $C$. materiae sp. nov. were physiologically very similar to $C$. jeffriesii and S. passilidarum. However, the novel yeast was not able to ferment D-xylose.

Two strains of C. materiae sp. nov. were isolated from yeast nitrogen base plus D-xylose as sole carbon source, whereas the third was isolated from the carboxymethylcellulose medium. However, the strain isolated using the carboxymethylcellulose medium was not able to produce extracellular cellulase (data not shown). The medium contained cellobiose, which can be utilized by C. materiae sp. nov. as a sole carbon source. S. passalidarum and C. jeffriesii are associated with wood-boring beetles that occur throughout the eastern USA and in Panama (Nguyen et al., 2006). The isolation of $C$. materiae sp. nov. from rotting wood

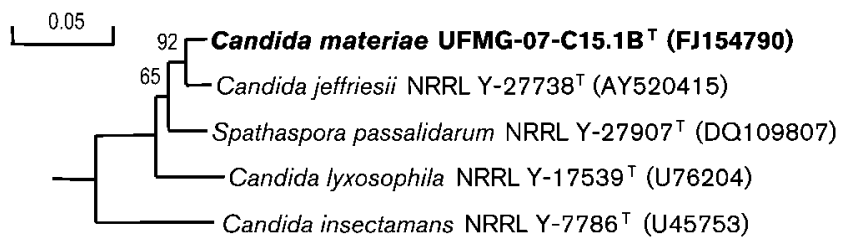

Fig. 1. Neighbour-joining tree showing the placement of Candida materiae sp. nov. among related species in the Spathaspora clade. Bootstrap values of $50 \%$ or above are shown. Bar, 5 substitutions per 100 nucleotides. suggests that this yeast was also introduced to this plant material by wood-boring insects that use this substrate.

C. materiae sp. nov. could be distinguished from C. jeffriesii based on growth at $37{ }^{\circ} \mathrm{C}$ and the fermentation of D-xylose. C. materiae sp. nov. gave a positive response for the first physiological test and a negative response for the second. $S$. passalidarum could be easily distinguished from C. materiae sp. nov. based on the ability to ferment D-xylose and the production of ascospores by the former species (Nguyen et al., 2006). C. insectamans was negative for assimilation of galactose and sucrose (Meyer et al., 1998), whereas the other species of the Spathaspora clade are able to use these sugar sources. Isolates of $C$. materiae sp. nov. were examined individually or mixed in pairs on cornmeal, V8, dilute V8, $5 \%$ malt extract, yeast carbon base supplemented with $0.01 \%$ ammonium sulphate and Gorodkowa agars, but asci or signs of conjugation were not observed.

\section{Latin diagnosis of Candida materiae Barbosa, Cadete, Gomes, Lachance et Rosa sp. nov.}

In medio liquido post dies tres cellulae singulae aut binae; cellulae ovoidae aut ellipsoideae $(2-3 \times 2-4 \mu \mathrm{m})$. Post unum mensem sedimentum formatur. Cultura in agaro malti post dies $2\left(17{ }^{\circ} \mathrm{C}\right)$ candida, convexa, rugosa et opalescens. In agaro farinae Zea mays post dies 14 pseudomycelium formantur. Glucosum at maltosum fermentatur. Glucosum, galactosum, L-sorbosum, sucrosum, maltosum, cellobiosum, trehalosum, melezitosum, D-xylosum, D-ribosum (lente), glycerolum, erythritolum, ribitolum, D-mannitolum, salicinum (variabile), acidum lacticum (variabile), acidum succinicum, acidum citricum (exigue), $\mathrm{N}$-acetylglucosaminum (exigue) et xylitolum (variabile) assimilantur, at nonlactosum, melibiosum, raffinosum, inulinum, amylum solubile, D-arabinosum, L-arabinosum, L-rhamnosum, ethanolum, galactitolum, glucitolum, meso-inositolum, methanolum, hexadecanum, D-glucosaminum, acetonum, 2-propanolum et ethyl acetas. Ethylaminum, lysinum et cadaverinum assimilantur at non-kalium nitricum et natrium nitrosum. Ad crescentiuam vitamina externa necessaria sunt. Augmentum in $37^{\circ} \mathrm{C}$. Habitat materiam in Brazil. Typus UFMG-07$\mathrm{C} 15.1 \mathrm{~B}^{\mathrm{T}}$. In collectione zymotica Centraalbureau voor Schimmelcultures, Trajectum ad Rhenum, sub no. CBS $10975^{\mathrm{T}}$ typus stirps deposita est.

\section{Description of Candida materiae Barbosa, Cadete, Gomes, Lachance \& Rosa sp. nov.}

Candida materiae [ma.te'ri.ae'. L. gen. n. materiae of a material, matter, referring to the substrate (wood) where this yeast was found].

In yeast extract $(0.5 \%)$, glucose $(2 \%)$ broth after 3 days at $25{ }^{\circ} \mathrm{C}$, the cells are ovoid to ellipsoidal $(2-3 \times 2-4 \mu \mathrm{m})$. Budding is multilateral (Fig. 2). A sediment is formed after a month, but a pellicle is not observed. On YMA after 2 days at $17{ }^{\circ} \mathrm{C}$, colonies are white, convex, rugose and opalescent. In Dalmau plates after 2 weeks on cornmeal 


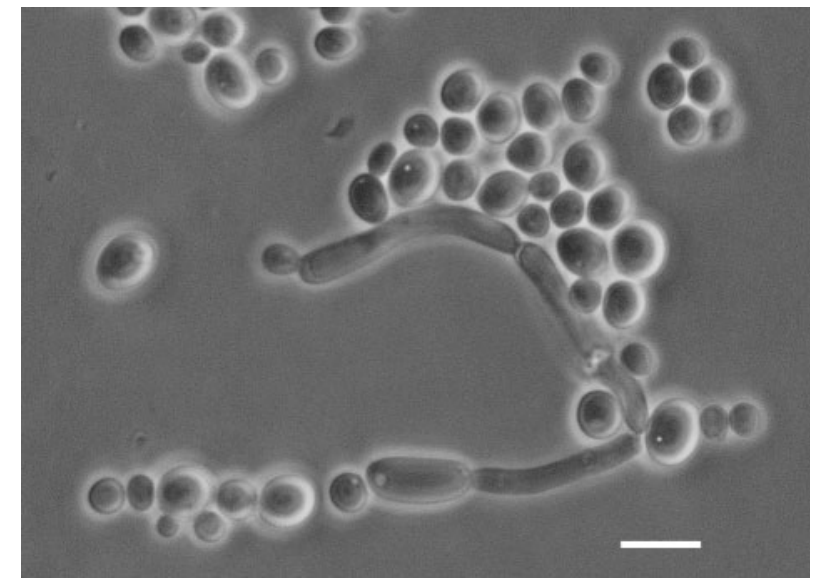

Fig. 2. Phase-contrast micrograph of cells of Candida materiae sp. nov. strain UFMG-07-C15.1 $\mathrm{B}^{\top}$ on yeast extract-malt extract agar after 5 days at $22^{\circ} \mathrm{C}$. Bar, $5 \mu \mathrm{m}$.

agar, pseudomycelia are formed. Ascospores are not formed. Fermentation of glucose and maltose is positive. The following carbon compounds are assimilated: glucose, galactose, L-sorbose, sucrose, maltose, cellobiose, trehalose, melezitose, D-xylose, D-ribose (slow), glycerol, erythritol, ribitol, D-mannitol, salicin (variable), lactic acid (variable), succinic acid, citric acid (weak), N-acetylglucosamine (weak) and xylitol (variable). No growth occurs on lactose, melibiose, raffinose, inulin, soluble starch, D-arabinose, Larabinose, L-rhamnose, ethanol, galactitol, glucitol, myoinositol, methanol, hexadecane, D-glucosamine, acetone, 2propanol and ethyl acetate. Assimilation of nitrogen compounds: positive for lysine, ethylamine- $\mathrm{HCl}$, cadaverine, and negative for nitrate and nitrite. Growth in vitamin-free medium is negative. Growth in amino-acidfree medium is positive. Growth at $37{ }^{\circ} \mathrm{C}$ is positive. Growth on YM agar with $10 \%$ sodium chloride is negative. Growth in $50 \%$ glucose/yeast extract $(0.5 \%)$ is negative. Starch-like compounds are not produced. In $100 \mu \mathrm{g}$ cycloheximide $\mathrm{ml}^{-1}$ growth is negative. Urease activity is negative. Diazonium Blue $B$ reaction is negative. The habitat is rotting wood in Atlantic rain forest ecosystem, in the state of Minas Gerais, Brazil.
The type strain of Candida materiae, UFMG-07-C15.1B ${ }^{\mathrm{T}}$, was isolated from rotting wood in Brazil. It has been deposited in the collection of the Yeast Division of the Centraalbureau voor Schimmelcultures, Utrecht, The Netherlands, as strain CBS $10975^{\mathrm{T}}$ (=CBMAI 956 ${ }^{\mathrm{T}}$ ).

\section{Acknowledgements}

This work was funded by Conselho Nacional de Desenvolvimento Cientifico e Tecnológico (CNPq, process no. 477528/03-1), Fundação do Amparo a Pesquisa do Estado de Minas Gerais (FAPEMIG, process no. CBB-378/04 and CBB APQ-3484-4.01/07), and the Natural Science and Engineering Research Council of Canada (M.-A. L.).

\section{References}

Kurtzman, C. P. \& Fell, J. W. (1998). The Yeasts, a Taxonomic Study. Amsterdam: Elsevier.

Lachance, M. A., Bowles, J. M., Starmer, W. T. \& Barker, J. S. F. (1999). Kodamaea kakaduensis and Candida tolerans, two new ascomycetous yeast species from Australian Hibiscus flowers. Can J Microbiol 45, 172-177.

Meyer, S. A., Payne, R. W. \& Yarrow, D. (1998). Candida Berkhout. In The Yeasts, a Taxonomic Study, 4th edn, pp. 454-573. Edited by C. P. Kurtzman \& J. W. Fell. Amsterdam: Elsevier.

Nguyen, N. H., Suh, S. O., Marshall, C. J. \& Blackwell, M. (2006). Morphological and ecological similarities: wood-boring beetles associated with novel xylose-fermenting yeasts, Spathaspora passalidarum gen. sp. nov. and Candida jeffriesii sp. nov. Mycol Res 110, 1232-1241.

Thompson, J. D., Higgins, D. G. \& Gibson, T. J. (1994). CLUSTAL W: improving the sensitivity of progressive multiple sequence alignment through sequence weighting, position-specific gap penalties and weight matrix choice. Nucleic Acids Res 22, 4673-4680.

van der Walt, J. P., Scott, D. B. \& van der Klift, W. C. (1972). Six new Candida species from South African insect sources. Mycopathologia 47, 221-236.

van der Walt, J. P., Ferreira, N. P. \& Steyn, R. L. (1987). Candida lyxosophila sp. nov., a new $\mathrm{D}$-xylose fermenting yeast from southern Africa. Antonie van Leeuwenhoek 53, 93-97.

Yarrow, D. (1998). Methods for the isolation, maintenance and identification of yeasts. In The Yeasts, a Taxonomic Study, 4th edn, pp. 77-100. Edited by C. P. Kurtzman \& J. W. Fell. Amsterdam: Elsevier. 